\title{
CHARAKTER A POSTAVENIE KOMIKSU V LITERATÚRE A VO FILME
}

\section{Character and Position of Comics in Literature and Film}

Keywords: comics, comic book, literature, film, popculture

Contact: Univerzita Pavla Jozefa Šafárika v Košiciach; basapetrova@gmail.com

Komiksová kultúra je neoddelitel'ne spájaná s popkultúrou. Hoci popkultúrne diskurzy sú v súčasnosti na vzostupe a disponujú vlastným terminologickým slovníkom, svoje miesto v akademickom prostredí si našli približne v 30. rokoch 20. storočia, inšpirované slovníkom frankfurtskej školy. Komiksy dnes vnímame ako moderné, zväčša súčasné texty, väčšinou prinášajúce príbeh o nejakom superhrdinovi.

\section{Historický vývoj komiksu}

Súvislosti s komiksami môžeme nájst' už v komunikačných systémoch ranej podoby civilizácie, kedy ešte neexistovalo písmo $\mathrm{v}$ takej forme, $\mathrm{v}$ akej ho poznáme dnes. „Možná jsme nedospěli k rozhodnutí, kam vlastně datovat vznik comicsu, ale můžeme $\mathrm{s}$ jistotou ř́ci, že pokusy vyprávět př́běhy prostřednictvím obrazu a textu se táhnou lidskou historií jako červená nit už od počátku věkưu“ (Kruml 2007: 16). Dôležité je datovanie miesta a času vzniku komiksov, rovnako ako ideológie, ktoré v danom období prevládali.

Počiatky komiksu môžeme zaznamenat' pri pravekých mal'bách. Na stenách španielskej jaskyne Altamira a v jaskynnom komplexe Lascaux vo Francúzsku môžeme vidiet' namal'ované lovecké príbehy. Nemajú však premyslenú sekvenčnú štruktúru, nie sú usporiadané v priestorovej juxtapozícii, rovnako im chýba časová postupnost'. Za predobraz komiksov tiež považujeme kombináciu egyptského obrázkového písma (hieroglyfy) a malieb, ktoré zaznamenávajú životy faraónov v chronologickej, časovej postupnosti (cca 1300 pr. Kr.). Hieroglyfy, rovnako ako naša abeceda, iba zastupujú znaky, samé o sebe nehovoria nič, preto samotné hieroglyfy nepovažujeme 
za predchodcov komiksu. „Skutečným potomkem hieroglyfů je písmo, nikoly komiks“ (McCloud 2008: 13).

Trajánov stíp, pomník postavený $\mathrm{v}$ Ríme $\mathrm{v}$ druhom storočí, je nielen jednou z najslávnejších starovekých sochárskych pamiatok. Ako prvá obrazová pamiatka určená verejnosti (200 metrov dlhá obrazová špirála), je historickým medzníkom aj v ponímaní komiksu. Ďalšou z historických, tentokrát stredovekých pamiatok, ktorá v sebe nesie jeho prvky, je Tapiséria z Bayeux, ktorá podrobne zobrazuje normandskú inváziu do Anglicka z roku 1066. Tento sedemdesiat metrov dlhý gobelín predstavuje jedinečný obrazový dokument, ktorý dopíňajú latinské texty. Jedinečnost’ diela spočíva vo využití celostranovej kompozície, ktorú tvorí celkom 58 obrazov. Túto kompozíciu ako jeden z mála autorov do dnešného dňa využíva komiksový autor Will Eisner (McCloud 2008: 12).

Rozvoju sekvenčného umenia v stredoveku napomáhalo rozšírené používanie symbolov. Negramotnost' väčšiny obyvatel'stva a prioritné postavenie cirkvi v spoločnosti prispeli k novému fenoménu, a to mal'ovaniu křest’anských výjavov následne vylepovaných $\mathrm{v}$ kostoloch. Módne bolo tiež zaznamenávanie života odsúdencov na plagáty, ktoré si bolo možné pri poprave kúpit', najmä v 14. a 15. storočí. Vd’aka týmto príkladom z histórie od staroveku po stredovek sme si vymedzili rôzne znaky, ktoré ovplyvnili súčasný tvar komiksu.

\section{Súvislosti s literatúrou}

Ďalším medzníkom nielen pre počiatok novoveku, ale aj pre vývoj komiksu a jeho súvislost' s literatúrou, je vynájdenie kníhtlače v 15. storočí, ktorá prispela k šíreniu písomnej kultúry všetkým vrstvám obyvatel’stva. Stále pretrvávalo ponímanie dvoch typov literatúry, rozlišujeme literatúru vysokú a nízku. Na toto delenie nemusíme nazerat' ako na výsledok delenia zhl'adiska estetických kritérií, môže íst' o výraz společenského poriadku alebo sociálneho usporiadania. To je mnohokrát dôsledok toho, že literatúra popisujúca nižšie vrstvy bola práve tou literatúrou, ktorou vyššie vrstvy opovrhovali.

Obrázkové príbehy dosiahli nový vrchol v 18. storočí, kedy karikaturista Wiliam Hogarth preferoval názor, že zavádzanie nových obsahov si vyžaduje aj nové formy. Jeho farebná a detailná kresba vtedajšej reality v kombinácii so zaznamenávaním textu do bublín spôsobila, že: „vytvořil žánr, který můžeme označit jako obrazový cyklus“ (Kruml 2007: 15). V diele s názvom Dráha pobehlice zobrazil na šiestich obrázkoch životný príbeh prostitútky pomocou sekvencie obrázkov. Jeho diela boli vystavované ako série obrazov a predávané ako sekvenčné súbory rytín. Týmto autorom 
sa inšpirovali aj d’alší, napríklad Thomas Rowlandson alebo James Gilray. So zdokonal'ovaním kníhtlače sa spája aj vznik prvých humoristických a satirických časopisov, medzi inými napríklad Le Caricature, Le Charivari vo Francúzsku, El Sol a Don Quijote v Španielsku, Punch vo Vel'kej Británii alebo Humoristické listy v Čechách.

Devätnáste storočie je pre komiks obdobím novátorských pokusov, medzi inými ohraničenie jednotlivých obrázkov a vzájomné prepájanie slov a obrázkov, ktoré pripisujeme Rodolpheovi Töpfferovi. Scott McCloud o ňom hovorí ako o „otcovi moderného komiksu“ (McCloud 2008: 17). Zásadné dielo v dejinách formovania komiksu vzniklo $\mathrm{v}$ roku 1895, kedy Richard Felton Outcalt zverejňoval príbehy o det'och z ulice New Yorku v časopise Truth, ktorý sa stal medzi čitatel'mi vel'mi populárny. Komiks mal názov The Yellow Kid a zo začiatku vychádzal bez textu, neskôr bol text napísaný na košeli hlavnej postavy. Postupom času sa ustanovila podoba písania do bublín. Tento komiks považujú odborníci za karikatúru. Tú od komiksu dôrazne odlišuje Mario Saraceni, ked' hovorí, že komiksy sú tvorené radom panelov tak, aby medzi každým d’alším panelom zostal prázdny biely priestor. To považuje za zásadný rozdiel medzi komiksami a karikatúrami, ktoré sú tvorené iba jedným panelom (Saraceni 2003: vol'ný preklad).

Prvým komiksovým hrdinom, ktorého považujeme za periodickú postavu zobrazovanú v komiksoch, je postava Ally Sloper, archetyp intrigána s červeným nosom, ktorého vytvoril anglický spisovatel' Charles Henry Ross. Už v tomto období sa začali ozývat' hlasy proti komiksom, ktoré prezentovali rôzni pedagógovia a moralisti. To zapríčinilo, že mnoho autorov prerobilo alebo úplne zrušilo svoje postavy.

Dvadsiate storočie je obdobím, ktoré pre komiks znamenalo zlatý vek, ale aj úpadok. Autori kreovali nové komiksové postavy, s ktorými sa snažili prerazit' $\mathrm{v}$ novinách. Inšpiráciami pre ich témy boli mnohokrát príbehy reálnych detí z ulice (ako v prípade The Yellow Kid), neskôr v komiksoch začali vyobrazovat' zvieratá. Samostatnou kapitolou je zobrazovanie žien v komiksoch. V tomto období hovoríme o prvých komiksových hrdinoch, ktorí si našli svoje stále publikum. Patria medzi nich napríklad Popeye, The Phantom alebo Mickey Mouse. S obdobím Druhej svetovej vojny a hospodárskej krízy sa spája obdobie, kedy vznikali prvé superhrdinské postavy ako Superman, Batman, Wonder Woman a pod. Ich popularita vrcholila počas trvania vojny, ich predaj sa neskôr čiastočne znížil kvôli publikácii amerického psychiatra Fredrica Werthama. Ten vo svojom diele Seduction of Innocent (Zvádzanie nevinných) ostro kritizoval komiksy, ktoré považoval za negatívnu formu populárnej kultúry a vážnou príčinou kriminality mladistvých. Kniha sa stala bestsellerom a podnietila kampaň v boji za cenzúru. 
Malá encyklopédia žurnalistiky z roku 1982 predstavuje pojem „comics, pôv. comic strips ako sled kresieb, ktoré majú nenáročný, zväšša komický dej, sprevádzaný najnevyhnutejším textom $\mathrm{v}$ podobe dialógu, resp. rozprávania a uverejňovaný ako súčast' seriálu“ (Jacz 1982: 59). Na základe tejto definície môžeme napríklad pozorovat' "vzt'ah" bývalého režimu ku komiksu, ktorý na neho nazeral ako na menejcenný žáner $\mathrm{s}$ banálnym obsahom určený predovšetkým pre čitatel’ov neschopných čítat' prozaické diela. Obrázkové znázornenia mali byt' akýmsi pomocníkom na porozumenie textu. Súčasný Slovník súčasného slovenského jazyka hovorí, že komiks je „synkretický žáner spájajúci výtvarné, literárne, dramatické a filmové prvky a postupy“ (Avramovová 2011: 235). Vnímanie komiksu ako literárneho žánru napomáhalo komunistickým ideológiám poukazovat’ na jeho chabú literárnu hodnotu.

Medzi znaky komiksu patrí hlavne sekvenčnost', ktorej komiks je hlavným zdrojom. Jeho vnímaniu ako súčasti literatúry predchádzajú dva znaky: komiks rozpráva príbeh a obsahuje verbálny text. Komiksový teoretik McCloud rozširuje jeho definíciu, ked' ho vytyčuje ako „záměrnou juxtaponovanou sekvenci kreslených a jiných obrazů, určenú ke sdělování informací nebo k vyvolání estetického prožitku“ (McCloud 2008: 9). Niektoré teórie komiks uvádzajú ako žáner epiky, oponenti ho kritizujú a nazývajú ho hybridom zložených z kresieb a krátkych textov v bublinách. Podl’a Eduarda Petrů má literatúra tri funkcie: „informatívnu, estetickú a formatívnu“ (Petrů 2000: 13). Informatívna funkcia umožňuje vidiet' istý súbor sémantických informácií o javoch alebo faktoch, ktoré sú predmetom literárnej reflexie. Formatívnou funkciou rozumieme vplyv literárneho diela na formovanie vzt’ahu percipienta $\mathrm{k}$ nemu. Nakoniec funkcia estetická, ktorá je z hladiska histórie najdôležitejšia, vytvára predpoklady a priestor pre estetický prežitok literatúry. Komiks spíňa všetky tri základné funkcie literatúry. Svoje miesto si našiel okrem iného predovšetkým v populárnej literatúre a v literatúre pre deti a mládež.

Sústavne zvyšujúca sa popularita komiksu je spájaná s mnohými spoločenskými, psychologickými, ale aj literárnymi aspektmi, pokial' sa do spoločenského kreovania tohto média nezapájajú ideológie. Komiks si vytvára svoje prostriedky a hranice, preberá prvky z jednotlivých umeleckých žánrov, nemožno ho preto posudzovat' iba z jedného hl'adiska. Pokial' nazeráme na komiks a na literatúru, môžeme komiks považovat' za primitívny (text je jednoduchý a neobsahuje vel'ké množstvo slovnej zásoby). Ich spoločným znakom je napriek nezrovnalostiam prítomnost’ rozprávača, ktorý je sprostredkovatel'om príbehu a dotvára komiks. Kto je rozprávačom v komikse? Mario Saranceni v knihe The Language of Comics uvádza, že v určitých prípadoch sa hlas rozprávača stáva rušivým a napáda reč postáv. Podl'a neho je niekedy zložité 
oddel'ovat' rozprávača a reč postáv (Saraceni 2003: vol'ný preklad). Komiks úzko súvisí s populárnou kultúrou, v tomto prípade s populárnou literatúrou. Vyniká dejovost'ou, vyvoláva účinok a komunikačný dosah. Príbehy v sebe zahŕňajú ponaučenie, výrazne vyniká emocionálna stránka, prítomné je napätie a vzrušenie. Ďalším zo znakov komiksu je, že nie sú zasadené do minulého času, ako to býva pri iných literárnych žánroch. Repliky sú písané v prítomnom čase, teda prekračujú sa hranice epiky a dochádza k dramatizácii deja. Tu sa dostávame k d'alšiemu odvetviu, s ktorým má komiks množstvo spoločných znakov.

\section{Súvislosti s filmom}

Vznik komiksu a filmu odborníci datujú do roku 1895. Odvtedy prešli obe médiá značným vývojom, ale tento rok sa pripisuje tak bratom Lumiérovcom, ktorí 28. decembra 1895 v Paríži premietli svoje prvé filmy, ako aj komiksu, konkrétnejšie 5. február 1895, kedy prvá komiksová postava - The Yellow Kid - dostala svoje meno. Rad odborníkov považuje za zrod komiksu až 25. október 1896, kedy jeden obrázok nahradilo viac obrázkov a reč postáv bola prvýkrát zobrazovaná v bublinách, nie na oblečení kreslených postáv (Kruml 2007).

Mnohé spoločné vlastnosti má komiks s filmom, podobá sa mu. Recipientovi je predložený komiksový príbeh v súčasnosti. Prebieha pred ním rovnako ako dej $\mathrm{v}$ divadle, filme alebo $\mathrm{v}$ televízii. Recipient vníma vizuálnu stránku diela, následne zvuk (vo filme) a text (v komikse). Na základe toho ho môžeme definovat' ako vizuálno - verbálne umenie.

Súvislosti medzi komiksami a filmami si predostrieme na príklade z histórie a koreláciou s filmovou produkciou. Vo filmovej tvorbe sa odrážajú napríklad významy v hieroglyfických grafických záznamoch. Nové možnosti významu nám dávajú princípy montáže izolovaných elementov a ich konfrontácia. „Film nekopíruje «objektivně», naturalisticky nebo kontinuálně nějakou realitu, jež se mu předkládá: ve filmu se oddělují sekvence, izolují se záběry a prostřednictvím nové montáže se znovu kombinují. Film nereprodukuje věci: manipuluje s nimi, uspořádává je, strukturuje je. A jeho elementy dostávají smysl pouze $\mathrm{v}$ nové struktuře získané jejich montáží، (Kristeva 1999: 47). Vo filme Krížnik Potemkin režiséra Ejzenštejna vidíme tri rôzne sochy leva izolované od ostatných záberov a usporiadané jedna za druhou, čím vytvárajú filmovú výpoved'. Kristeva hovorí, že film podl'a Ejzenštejna musí byt': „hieroglyfickým textem, jehož každý izolovaný element má smysl jen v kontextuální kombinatorice a v závislosti na svém místě ve struktuře“ (Kristeva 1999: 47). $\mathrm{Na}$ základe hieroglyfov si všímame spoločný znak filmu a komiksu, ktorým je 
sekvenčnost' alebo oddel'ovanie záberov. Zároveň je to jednou zo základných definícií komiksu: komiks je hlavným zdrojom sekvenčného umenia (Eisner 1985). Ako hlavný znak poukazuje na sekvenciu minimálne dvoch obrázkov. Tu sa môžeme pozriet' na súvis medzi animovanými filmami a komiksom. Sekvencia pri animácii prebieha $\mathrm{v}$ čase, zatial' čo sekvencia pri komiksoch prebieha $\mathrm{v}$ priestore. Film sa premieta na ten istý priestor (plátno alebo obrazovka), zatial' čo pri komikse má každý panel svoje miesto. „V komiksu hraje prostor právě tú roli, kterou u filmu hraje čas“ (McCloud 2008: 7). Obraz nemá prevládat' nad textom, prevládat' má naratívna a estetická funkcia. Sekvencia pri animácii prebieha $\mathrm{v}$ čase, zatial' čo sekvencia pri komiksoch prebieha v priestore. Film sa premieta na ten istý priestor (plátno alebo obrazovka), zatial' čo pri komikse má každý panel svoje miesto.

D. Kokeš sa vo svojej knihe zaoberá výkladovou pružnost'ou komiksového formátu, ked' hovorí o možnom vplyve umeleckej formy komiksu na systém filmového diela. Na príklade filmu Kdo chce zabít Jessii hovorí o nesúlade filmových a komiksových postupov, kedy prenikanie komiksovej estetiky je skôr umeleckým nástrojom ako cielom. Využitím rôznych komiksových princípov vo filme docielili vznik diela, ktoré bolo rovnomerne odsudzované a prijímané. Poetika komiksu sa vo filme uskutočňuje $v$ troch rovinách:

1. rovina rozprávania;

2. rovina fiktívneho světa;

3. rovina štylistických postupov.

Film obsahuje dva komiksové postupy, konkrétne prácu s namal'ovanými statickými obrazmi a prácu s mizanscénou. Kritiky ho označovali ako paródiu na komiks a ironickou zábavou, zatial' čo autori tvrdili, že paródiou je maximálne z tridsiatich percent (Kokeš 2015: 129-131).

\section{Superhrdina a popkultúrny hrdina}

Literárny, filmový, ale aj komiksový hrdina má svoje špecifiká. V článku sa zaoberáme rozdielmi medzi hrdinom, superhrdinom a popkultúrnym hrdinom. Práve hrdina je subjektom, ktorého identifikáciou môžeme vidiet' odlišnosti medzi literatúrou, filmom a komiksami. „Superhrdina disponuje na rozdiel od hrdinu nielen mimoriadnymi osobnými vlastnost’ami, nútiacimi $\mathrm{v}$ hraničných situáciách správat' sa $\mathrm{z}$ hl'adiska morálneho kódexu $\mathrm{v}$ súlade $\mathrm{s}$ ideálom, ale aj schopnost’ami, prirodzenými či nadprirodzenými, reálne prekračujúcimi medze uveritel’nosti, hranicu medzi akože a naozaj“ (Malíček 2008: 16). Malíček d’alej hovorí o popkultúrnom hrdinovi, ktorého 
definuje ako samotára, nositel'a vlastného morálneho kódexu, d’alej ako schizofrenika, ktorý je na jednej strane hrdinom a na strane druhej civilnou bytost'ou. Popkultúrny hrdina podl'a Malička nemá bohatý vnútorný život (na rozdiel od jeho civilného alter ega), nedochádza u neho k osobnostným zmenám a nemá vel'a priatel’ov. Medzi typický a univerzálny znak zarad'uje to, že každý popkultúrny hrdina je budovatel'om a nositel’om vlastného mýtu (Malíček 2008: 16-17). Považujeme komiks za umelecký výtvor? Prostredníctvom citátu od Malíčka sa vrátime k jeho umiestneniu do oblasti filmu alebo literatúry. „Pravým domovom popkultúrneho hrdinu nie je domovský popkultúrny artefakt, ale vedomie, mysel', fantázia, celkom konkrétnych recipientov, čitatel'ov a divákov..." (Malíček 2008: 25). Toto tvrdenie môžeme transformovat' na vnímanie komiksu $\mathrm{v}$ dnešnej spoločnosti, ktorého pravým domovom je rovnako mysel', fantázia a vedomie recipienta. Svoje miesto vo svete literatúry, filmu alebo všeobecne umenia, si komiks postupne nachádza aj napriek odlišným konštrukciám diskurzu.

\section{Záver}

Obsah čítania a vnímania komiksu je totožný ako pri čítaní literárnych diel a pozeraní filmov (alebo seriálov). Naratívna funkcia zobrazuje plynutie času v nazeraní do minulosti alebo do budúcnosti, čo je rovnaké v prípade literatúry aj filmu. Komiks preto $\mathrm{v}$ dnešnej dobe naberá $\mathrm{v}$ akademickom prostredí vážnost'. Niektorí odborníci ho už považujú za samostatné, tzv. „,deviate umenie“, teda za nezávislú umeleckú formu. Odmietajú ho dávat' do súvislostí s literatúrou, filmami alebo žánrami. Kanadský teoretik médií Marshall McLuhan dokonca zaradil komiks medzi samostatné médiá, pretože definoval odlišnosti komiksu z viacerých hl'adísk na úrovni narácie. Primárnym kódom v literatúre je jazyk, zatial' čo komiks kladie rovnaký dôraz aj na obraz, preto nedáva do súvislostí komiks ani so žánrami. Preto za opodstatnený posun považuje adaptácie komiksových diel (McLuhan 1991: 159-160).

\section{Summary}

European comics scholar Thierry Groensteen explains that the rich diversity that is attributed to comics makes it almost impossible to set any defining criteria that would be universally valid. In line with this assumption, we can see that the criteria determining the general status and classification of comics have not been clearly established. There have been different approaches to comics in varied studies. Some theorists regard comics as a medium whereas others define it as a hybrid genre. This paper attempts to explore comics in a broader context of literature and film. We have detected some 
common features of all these industries which then provided us with a sound foundation for establishing the status of comics among them, which we demonstrate on individual examples.

\section{Literatúra}

Avramovová, M. et al. Slovník súčasného slovenského jazyka. Bratislava: Veda, 2011.

Eisner, W. Comics \& Sequential Art. Florida: Poorhouse Press, 1985.

Groensteen, T. Stavba komiksu. Brno: Host, 2015.

Jacz, L. et al. Malá encyklopédia žurnalistiky. Bratislava: Obzor, 1982.

Kristeva, J. Slovo, dialog a román: Texty o sémiotice. Praha: Sofis - Pastelka, 1999.

Kokeš, R. D. Rozbor filmu. Brno: Filozofická fakulta Masarykovy univerzity, 2015.

Kruml, M. Comics: Stručné dějiny. Praha: Martin Trojan, 2007.

Malíček, J. Hl’a, popkultúrny hrdina (Typológia popkultúrneho hrdinu). In: Malíček, J. (ed.) Zborník o populárnej kultúre. Nitra: Univerzita Konštantína Filozofa v Nitre, 2008, s. 16.

McCloud, S. Jak rozumět komiksu. Praha: BB/art., 2008.

McLuhan, M. Jak rozumět médiim. Praha: Odeon, 1991.

Petrů, E. Úvod do studia literární vědy. Olomouc: Rubico, 2000.

Saraceni, M. The Language of Comics. London: Routledge, 2003. 